\title{
Problematyka społeczno-gospodarcza w działalności Stanisława Mikołajczyka
}

Działalność Stanisława Mikołajczyka byłaby niepełna bez ukazania jego pracy na niwie społeczno-gospodarczej. Gdy w 1946 roku Mikołajczyk odwiedził Krotoszyn, powiedział do witających go Wielkopolan: „Tu dorastały w umyśle moim te myśli $\mathrm{i}$ te przekonania, które kształtowały mą późniejszą ideologię polityczną". A trzeba pamiętać, że rodziły się one i rozwijały pod wpływem bogatych tradycji pracy organicznej, przywiązania do narodu i ojczyzny. Opierając się na tych wartościach, młody Mikołajczyk pragnął działać, służąc Polsce i społeczeństwu. Swój życiowy program zaczął realizować jako ochotnik w Powstaniu Wielkopolskim i w wojnie polsko-bolszewickiej. W Polsce niepodległej poświęcił się działalności organizacyjnej na wsi i w ruchu ludowym. Szkołą aktywności społecznej były dla Mikołajczyka organizacje młodzieżowe, kółka rolnicze, spółdzielczość oraz Polskie Stronnictwo Ludowe „Piast” i Stronnictwo Ludowe.

\section{Wielkopolskie Towarzystwo Kółek Rolniczych}

Pracę społeczną Mikołajczyk rozpoczął od działalności w najbliższym otoczeniu. W 1921 roku, mając zaledwie dwadzieścia lat, wstappił do Kółka Rolniczego w Dobrzycy w ówczesnym powiecie krotoszyńskim. To, że Mikołajczyk na drodze swej społecznej aktywności pierwsze kroki skierował do tej organizacji, nie było dziełem przypadku. Należy pamiętać o tym, iż w okresie rozbiorów kółka rolnicze zapisały chlubną kartę w codziennej pracy chłopów wielkopolskich. Przyczynity się do rozwoju rolnictwa, kultury rolnej i obrony bytu narodowego. Dla Mikołajczyka praca w kółkach rolniczych to nie tylko krok $\mathrm{ku}$ scenie politycznej, ale też ważna funkcja społeczna. Zaczynał swą działalność od najniższego szczebla, ale najbliższego mieszkańcom wsi, na którym decydowano o wielu sprawach ich dnia codziennego. Mimo młodego wieku wnet dał się poznać jako aktywny i wyróżniający się działacz. Szybko awansował. W 1928 roku został członkiem Rady Głównej Wielkopolskiego Towa- 
rzystwa Kółek Rolniczych (RG WTKR). Należy pamiętać, iż gremium to składało się z tradycyjnych autorytetów w sprawach rolniczych (ziemianie, księża $\mathrm{i}$ inni). Musiał więc pod wieloma względami im dorównywać, skoro Walne Zgromadzenie uhonorowało go tym stanowiskiem. Nie był to awans chwilowy. W następnych latach Mikołajczyk pozostał członkiem Rady Głównej, aż do wyboru na stanowisko prezesa. Wchodził tákże w skład różnych komisji. W latach 1932-1933 był członkiem Komisji Rewizyjnej i wiceprzewodniczącym Komisji Osadniczej oraz członkiem Komisji Oświatowej, a w latach 1934-1935 ponownie pracował w Komisji Rewizyjnej. Piastował równiez mandat radcy w Wielkopolskiej Izbie Rolniczej (WIR). Wchodził w skład poznańskiego samorządowego sejmiku wojewódzkiego, gdzie przewodniczył Wydziałowi Rolnictwa. Na Walnym Zgromadzeniu WTKR w dniu 25 czerwca 1936 roku S. Mikołajczyk otrzymał godność prezesa. Wybór na to stanowisko otworzył mu szerokie pole dla dalszej pracy społecznej".

Jako prezes WTKR był jednym z założycieli spółki elektryfikacyjnej. 15 października 1938 roku powołano. Towarzystwo Elektryfikacyjne Okręgu Poznańskiego S.A. Członkami spółki były osoby prawne, a więc różnego rodzaju instytucje, a przede wszystkim zwiazzki samorządu terytorialnego. Mikołajczyk znalazł się w zarządzie spółki i został wybrany przewodniczącym Sekcji Wiejskiej Komitetu Elektryfikacyjnego. Spółka zgromadziła poważny, jak na owe czasy, kapitał zakładowy w wysokości 1,5 miliona złotych. Rozpoczęto również prace organizacyjne i budowlane. Przystapiono do wznoszenia elektrowni w Poznaniu, położonej w pobliżu Warty. Prace przy jej realizacji postępowały w szybkim tempie. W poszczególnych miastach i wsiach rozpoczęto również budowę sieci elektrycznej, jednak wybuch II wojny światowej nie pozwolił dokończyć rozpoczętych inwestycji. Kontynuowali je Niemcy, a ostatecznie ich realizację zakończono po wojnie.

Mikołajczyk jako przedstawiciel wielkopolskiego rolnictwa w swojej działalności zajmował się zagadnieniami, którymi żyła ówczesna wieś. Przywiązywał dużą wagę do roli, jaką dobrowolne organizacje rolników odgrywały w życiu gospodarczym. Uważał, iż samoorganizowanie się chłopów jest podstawą sprawnie funkcjonującego rolnictwa ${ }^{2}$. Służy bowiem zarówno przezwyciężaniu sił przyrody, jak i wszelkich przeciwieństw natury społecznej i politycznej. W związku z potrzebami polskiego rolnictwa i mieszkańców wsi była niezbędna - jego zdaniem - odpowiednia polityka państwa. Jednak nawet najlepsza prorolnicza działalność nie mogłaby odnieść pozytywnego skutku bez

\footnotetext{
${ }^{1}$ Stanisław Mikołajczyk w Stronnictwie i w Parlamencie (1945-1947). Przygotował do druku i biografią S. Mikolajczyka poprzedził S. Stępka, Szreniawa 1992, s. 9-10.

${ }^{2}$ „Poradnik Gospodarski" nr 46 z 15 XI 1936 r., s. 816, 817.
} 
świadomego i bezinteresownego zaangażowania w pracy społecznej samych chłopów. Powinni oni bowiem wspierać wysiłki państwa, zarówno dla odciążenia jego instytucji, jak i celem zabezpieczenia rolnictwa przed nadmierną ingerencją urzędników.

Kółka rolnicze, jako dobrowolne organizacje, umożliwiały samorządowi rolniczemu odpowiednie oparcie w terenie. Same poprzez współpracę z izbami rolniczymi pracowały nad podnoszeniem kultury, obroną zawodowych interesów rolników i wpływały na politykę gospodarczą państwa. Dobrowolna organizacja rolników, mimo kilkudziesięcioletniej ewolucji, zachowała najważniejsze swoje cechy i zadania. „Podstawowe właściwości - zdaniem Mikołajczyka - dobrowolnej organizacji, jakimi są niezależność i odwaga we wskazywaniu na te lub inne ujemne objawy - przesądzają w sensie dodatnim o wartości pracy i znaczeniu dobrowolnej organizacji, jako czynnika powołanego do obrony interesów zawodowych. Jedynie kontrola opinii społecznej ustrzec może naród i państwo przed błędami, których konsekwencje mogą być ciężkie"3.

Przy każdej sposobności podkreślał, że kółka rolnicze potrafiły zachować samodzielność i apolityczność. W przyszłości każdy członek tej organizacji powinien mieć własne poglądy $\mathrm{w}$ sprawach politycznych, państwowych i ustrojowych. Z kolei w' kwestiach gospodarczych, oświatowych i społecznych wszyscy członkowie organizacji gospodarczej, niezależnie od orientacji politycznej, powinni współpracować dla dobra wsi i rolnictwa. Zdecydowanie opowiadał się za powszechnością kółek rolniczych. Zasada ta miała opierać się na dobrowolnym i świadomym dążeniu chłopów do podejmowania wspólnego wysiłku na rzecz rolnictwa i społeczności lokalnej. Administracji państwowej stawiał zarzut, iż dąży do mechanicznego forsowania pewnych rozwiazzań, w tym także w sprawie przynależności do organizacji rolników. Przestrzegał przed dążeniem do przyspieszania procesu umasowienia kółek rolniczych. W pierwszej kolejności wszelkie idee docierają do jednostek światłych i otwartych na zmiany. Dopiero za ich pośrednictwem, poprzez przykłady i osiagane wyni$\mathrm{ki}$, na wsi upowszechnia się zdobycze wiedzy i kultury rolnej ${ }^{4}$.

\section{Spółdzielczość wiejska}

Ważne miejsce w rozwoju rolnictwa Mikołajczyk rezerwował dla spółdzielczości wiejskiej. Zastanawiał się nad przyczynami załamania się ruchu spółdzielczego w latach trzydziestych. Genezę tego zjawiska widział w kryzy-

\footnotetext{
${ }^{3}$ Ibidem, s. 817.

"Poradnik Gospodarski" nr 26 z 27 VI 1937 r., s. 419; nr 7 z 12 II 1939 r., s. 108; nr 9 z 26 II 1939 r., s. 140.
} 
sie ekonomicznym. Zapewniał, że WTKR będzie wspierać wszelkie działania zmierzające do odbudowy i umocnienia spółdzielczości na wsi. Uważał, że interes rolnictwa wiąże się bezpośrednio ze spółdzielczością. „Gdzie więc, jak nie na terenie powiatowych towarzystw kółek rolniczych - pisał $w » P o r a d n i k u$ Gospodarskim« - należy regulować inicjatywę zakładania nowych spółdzielni, wytyczać rejony działania celem uniknięcia konkurencji, łączyć możliwości i doświadczenia nad odbudową starych i rozbudową nowych spółdzielni"s. Spółdzielczość wiejska w rozumieniu Mikołajczyka miała wspierać rolnictwo. Bronić go przed niezdrową konkurencją oraz wpływać na opłacalność produkcji. Spółdzielczość miała być kluczem do uzyskania przez rolnictwo wpływów na rozwój handlu i przemystu. W swoich wystapieniach zdecydowanie wykluczał pojmowanie spółdzielczości jako zaczynu „(...) przyszłego kolektywnego ustroju państwowego w życiu gospodarczym".

Ze strony władz państwowych i samorządu lokalnego Mikołajczyk oczekiwał większego wsparcia dla spółdzielczości. W tym celu określił jej potrzeby, których spełnienie powinno zagwarantować odpowiedni rozwój. W 1938 roku ich katalog przedstawił w następujący sposób:

„1. Należy dążyć do jak największego rozszerzenia kompetencji urzędów rozjemczych w dziedzinie oddłużenia spółdzielni.

2. Zwolnić gwarantów od współodpowiedzialności za spółdzielnie.

3. Należy dążyć do jak najszybszego zakończenia akcji oddłużeniowej i porządkowej na terenie spółdzielczym.

4. Zwiększyć sumy przeznaczone na załatwienie tego zagadnienia.

5. Przeznaczyć pewne sumy na kapitał obrotowy tutejszej spółdzielczości.

6. Należy dążyć do zmiany ustawodawstwa w kierunku obowiązku przyjmowania na członków spółdzielni rolników dostawców"\%.

\section{Sytuacja w rolnictwie}

W swojej działalności społeczno-politycznej odnosił się krytycznie do polityki gospodarczej obozu rządzącego, przy czym nie ograniczał się do zarzutów czysto ekonomicznych, choć i takich nie szczędził kolejnym ministrom odpowiedzialnym za rolnictwo. Domagał się ograniczenia wpływu karteli na życie gospodarcze. Tolerowanie przez rząd wysokich cen kartelowych - jego zdaniem - przyczyniło się do pogłębienia istniejącego kryzysu gospodarczego.

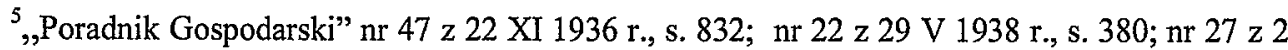
VII 1939 r., s. 455.

${ }^{6}$,Poradnik Gospodarski” nr 22 z 29 V 1938 r., s. 382.
} 
Domagał się obniżenia, przynajmniej o połowę, cen na podstawowe artykuły przemysłowe oraz zniesienia karteli. W wystapieniu sejmowym z 8 lutego 1933 roku oskarżył resort rolnictwa o to, że kiedy ceny artykułów rolnych spadły prawie o $60 \%$, dopuścił do obniżenia cen na buraki, zamiast szukać innych źródeł pokrycia dochodu kartelu cukrowniczego. W imieniu swoich wyborców żądał obniżenia, przynajmniej o połowę, cen na podstawowe artykuły przemysłowe oraz zniesienia karteli. Obok problemu karteli oraz niekorzystnych relacji cen, dużo miejsca poświęcił obciążeniom podatkowym wsi ${ }^{7}$. Wyjaśniał w Sejmie, w imieniu swoich wyborców, iż chłopi nie uchylają się od obowiązków na rzecz państwa. Zdają sobie bowiem sprawę, że ponoszą współodpowiedzialność za państwo, a trudna sytuacja kraju położy się cieniem na losach wsi. Stanowczo domagał się, aby rząd stworzył warunki dla realizacji chłopskich zobowiązań ${ }^{8}$. Przeciwstawiał się natomiast wszelkim próbom obciążania wsi nowymi podatkami.

W drugiej połowie lat trzydziestych, mimo stopniowej poprawy sytuacji ekonomicznej, w dalszym ciągu poważnym ciężarem dla gospodarstw, a szczególnie osadniczych, było zadłużenie. Chcąc przyjść rolnictwu z pomoca, zwołano na 21 maja 1939 roku do Poznania sejmik oddłużeniowy, w którym uczestniczyły Wielkopolskie i Pomorskie Towarzystwa Kółek Rolniczych. Nieprzypadkowo roli gospodarza podjęło się WTKR. Prezes Mikołajczyk już od dłuższego czasu alarmował, że akcja oddłużenia rolnictwa nie przynosi spodziewanych rezultatów. Przyczyn niepowodzeń tego zjawiska szukał w samym charakterze całej operacji, która miała charakter działań doraźnych. Cały proces miał bowiem likwidować skutki zadłużenia, a więc zapobiegać egzekucji zadłużonych gospodarstw. Jednak w momencie gdy upływał termin ochronny, cała akcja traciła na wartości. Proponował, aby oddłużenie wspierać działaniami na rzecz podniesienia opłacalności produkcji rolnej ${ }^{9}$.

Oprócz działań na rzecz oddłużenia polskiego rolnictwa Mikołajczyk zwracał uwage władzom państwowym, iż wieś potrzebuje kredytów. Uważał, że potrzebne są kredyty długoterminowe zarówno na inwestycje w gospodarstwach, jak i na spłaty rodzinne i zaliczkowe. Bez tych ostatnich trudno byłoby - jego zdaniem - zachować ,(...) zdrowe tradycje niedzielenia gospodarstw włościańskich".

Odrębne miejsce w działalności Stanisława Mikołajczyka zajmuje Wielkopolska. Rolnictwo na tym terenie uważał za wzór dla innych regionów kraju.

\footnotetext{
${ }^{7}$ A. Paczkowski, Stanisław Mikołajczyk czyli klęska realisty, Warszawa 1991, s. 25; S. Stępka; Stanisław Mikołajczyk, Warszawa 2001, s. 98.

${ }^{8}$ Sprawozdanie stenograficzne z 10. posiedzenia Sejmu RP, 6 lutego 1931 r., lamy 104-112.

${ }^{9}$, Poradnik Gospodarski”" nr 26 z 27 VI 1937 r., s. 422.
} 
Jednocześnie domagał się dla niego pewnych koncesji. Uważał, iż wielkopolskie rolnictwo w skali kraju powinno pełnić funkcję głównego producenta na rynki zagraniczne. Ponadto, ze względu na wysoką kulturę rolną powinno zaopatrywać rolnictwo polskie w wysoko kwalifikowany materiał siewny. Wskazywał także na specyficzne - dla tego regionu - przyczyny głębokiego kryzysu w rolnictwie. Zaliczył do nich m.in. nałożenie się w tym regionie działań kryzysowych $\mathrm{z}$ niepomyślnymi zjawiskami atmosferycznymi ${ }^{10}$. Wskazywał na wzrastająca falę reemigracji francuskiej oraz zbyt rygorystyczną politykę państwa na tym terenie. Jego zdaniem, z Wielkopolski odprowadzano zbyt dużo kapitału do innych części kraju, a wysokie świadczenia powodowały, iż region „(...) nie może odnotować poprawy"11.

Po zakończeniu II wojny światowej, w nowej zmieniającej się sytuacji, problem rolnictwa i trudności wynikających z ogromnych zniszczeń był nadal aktualny. Mikołajczyk jako wicepremier i minister rolnictwa i reform rolnych Tymczasowego Rządu Jedności Narodowej (TRJN) poświęcał temu zagadnieniu dużo uwagi. W referacie wygłoszonym podczas 9. sesji Krajowej Rady Narodowej (KRN) wskazał na trudności, jakie wystapiły w gospodarstwach rolnych. Przyczyn tego zjawiska upatrywał w spadku pogłowia, kłopotach transportowych i wprowadzeniu obowiązkowych dostaw. Przestrzegał przed możliwością odrodzenia zagrożenia niemieckiego. Uważał, że należy pozbawić Niemcy podstaw ekonomicznych, aby nie dopuścić w przyszłości do odbudowy ich potęgi militarnej. Ważnym etapem do realizacji tego celu miało być odpowiednie zagospodarowanie ziem zachodnich. W dalszej części wystąpienia wskazał na trudności gospodarcze państwowych majątków ziemskich. Obok przyczyn ekonomicznych, zauważył inne niekorzystne zjawiska, które nie wystapiły, mimo wielu trudności, w gospodarstwach chłopskich. Należały do nich: kłopoty z odtworzeniem majątku, powszechny brak poczucia własności oraz rozrzutność i niegospodarność powierzonym mieniem. Podczas posiedzenia KRN 3 stycznia 1946 roku Mikołajczyk jeszcze raz powrócił do problemu własności w rolnictwie, który, jak widać, uznał za istny problem i źródło trudności. Jego zdaniem, „(...) stosunek do tego obszaru jest jak do pańskiego. Stąd też szanowanie tego, co na tym ośrodku się znajduje, jest daleko mniejsze, aniżeli wtedy, kiedy chodzi o własne gospodarstwo chłopskie"12.

\footnotetext{
${ }^{10}$ S. Kowal, Wielkopolska działalność Stanisława Mikołajczyka w latach 1919-1939, „Kronika Wielkopolski” 1990, nr 2, s. 11; „Poradnik Gospodarski” nr 26 z 26 VI 1937 r., s. 422 ; nr 7 z 13 II 1938 r., s. 104.

"11 Poradnik Gospodarski" nr 26 z 26 VI 1938 r., s. 469.

${ }^{12}$ Sprawozdanie stenograficzne $z$ 3. posiedzenia KRN 29, 30 i 31 grudnia 1945 r. oraz 2 i 3 stycznia 1946 r., lamy $377-378 ; 381-382$.
} 


\section{Reforma rolna}

Realizowana w okresie międzywojennym reforma rolna - zdaniem Mikołajczyka - powinna przede wszystkim objąć parcelacją majątki prowadzone nieekonomicznie. Jako zwolennik przebudowy ustroju rolnego pisał na ten temat: „Zagadnienie reformy rolnej nie jest i nie może być traktowane jako czynnik agitacyjny dla przyciągnięcia członków. Dla Stronnictwa Ludowego nie to jest rzeczą najważniejszą, czy Wojciech lub Bartłomiej, zapisani członkowie SL, dostaną kawałek gruntu przy parcelacji, lecz to, ile ziemi w ogóle przejdzie w ręce tych, którzy nie pracują i czy okaże się to dla państwa i narodu korzystne"13. Widział konieczność tworzenia w Polsce samowystarczalnych gospodarstw nie tylko ze względu na ekonomiczne interesy rolnictwa, ale przede wszystkim ze względu na bezpieczeństwo państwa. Optymalnym celem reformy rolnej powinno być tworzenie gospodarstw, które dawałyby warunki rozwoju. Obawiał się, że jeżeli państwo dopuści w trakcie reformy rolnej do zbyt dużego rozdrobnienia rolnictwa, to spowoduje radykalizację nastrojów na wsi. Rolnicy staną się podatni na propagandę komunistyczną. Pisał w tej sprawie na łamach krakowskiego „Piasta”: „Wypowiadam sie przeciw dalszemu proletaryzowaniu wsi, gdyż musi to prowadzić do jej socjalizacji. Jestem zwolennikiem jak najwyższego wykształcenia i najlepszego przygotowania chłopa polskiego pracującego na zdrowym warsztacie rolnym, powstałym $z$ przebudowy ustroju"14.

Mikołajczyk występując w sprawie reformy rolnej miał na uwadze nie tylko ekonomiczne aspekty tego procesu, grożące stworzeniem zbyt dużej liczby drobnych gospodarstw, niezdolnych do towarowej produkcji, lecz również konsekwencje społeczne tego zjawiska. Wskazywał na nieunikniony proces pogłębiania się proletaryzacji wsi i radykalizacji jej postaw politycznych. Zwracał uwagę na znaczny stopień partycypacji w parcelacji rządowej robotników folwarcznych, niewielki natomiast samych chłopów, dla których znacznie korzystniejsze były warunki parcelacji prywatnej. Niepokojem napawały go także koncepcje rządowe zmierzające do uczynienia z ziem zachodnich głównej bazy dla osadnictwa rolnego, mającego rozładować lub przynajmniej złagodzić istniejące przeludnienie wsi w Polsce południowo-wschodniej. Swymi obawami w tej kwestii podzielił się Mikołajczyk z czytelnikami „Przeglądu Gospodarskiego". Pisał na jego łamach na ten temat: „Nadzieję przygotowanych na ojcowskim gospodarstwie i w szkołach rolniczych synów włościańskich na uzy-

\footnotetext{
${ }^{13}$ „Zielony Sztandar" nr 23 z 31 V 1936 r., s. 3.

${ }^{14}$ "Piast" nr 21 z 22 V 1938 r., s. 2.
} 
skanie warsztatu pracy w związku ze wzmożonym wykonywaniem reformy rolnej zabija wieść, że dużą część tych osad otrzymają osadnicy z innych części kraju". Szczególnie gorzko odbierał argumentację usprawiedliwiającą podejmowane działania rzekomą podatnością Wielkopolan na procesy germanizacyjne. Takie stanowisko uważał Mikołajczyk za niesprawiedliwe dla ludzi, którzy przetrwali pruską niewolę i wnieśli swój wkład w odbudowę państwa ${ }^{15}$.

$\mathrm{Na}$ temat reformy Mikołajczyk wypowiadał się także na forum parlamentu. Oskarżył sanację o zahamowanie przebudowy rolnictwa. W sytuacji gdy wieś była przeludniona, a w miastach występowało bezrobocie, reforma mogłaby jego zdaniem - złagodzić skutki tych zjawisk. W swoich postulatach uwzględniał także potrzeby osadników. Wskazywał na zbyt duże obciążenie tych gospodarstw. W osadnictwie rentowym nowy właściciel musiał zapłacić pełną cenę i regulować na bieżąco rentę, natomiast od właścicieli gospodarstw powstałych w wyniku osadnictwa likwidacyjnego urzędnicy często ściągali zaległości po byłych właścicielach niemieckich. Dotyczyło to szczególnie tych przypadków, gdy osadnik chciał sprzedać swoje gospodarstwo. Mikołajczyk wzywał rząd i resort rolnictwa do udzielenia pomocy osadnikom. W tej kwestii zgłosił w imieniu swoim i Klubu Posłów Chłopskich trzy wnioski. Dotyczyły one: obniżenia waloryzacji rent $w$ gospodarstwach rentowych, przewłaszczenia osad sprzedanych przez były Urząd Osadniczy i przesunięcia przez Państwowy Bank Rolny terminu płatności rent amortyzacyjnych, pożyczek udzielanych parcelantom, tak aby ich spłata rozpoczęła się dopiero od 1934 roku $^{16}$.

Mikołajczyk jako prezes WTKR deklarował wsparcie tej organizacji dla osadników. Pisał w tej kwestii w „Poradniku Gospodarskim”: „WTKR przez swą Sekcję Osadniczą i Gospodarstwa Przodownicze będzie jak najżywiej współpracować z osadnikami, dążąc nie tylko do utrwalenia ich stanu posiadania przez odpowiednie ustawodawstwo, dostosowujące wysokość świadczeń do możliwości płatniczej osadnika, ale w nie mniejszym stopniu czuwać będzie nad podniesieniem sprawności produkcyjnej gospodarstw osadniczych. Za dużo państwo polskie włożyło w przebudowę ustroju rolnego, by nie było naszym obowiazkiem jak najszybsze oprocentowanie kapitału tam włożonego, przez wciaganie i podnoszenie gospodarstw osadniczych, jak i osadnika samego do coraz wyższego poziomu w jak najrychlejszym terminie"17. Dobrze zaplano-

\footnotetext{
${ }^{15}$ „Poradnik Gospodarski” nr 1 z 1 I 1937 r., s. 4; nr 26 z 27 VI 1937 r., s. 423; B. Okoniewska, Początki działalności politycznej Stanisława Mikołajczyka na tle charakterystyki wielkopolskich środowisk rolniczych, „Kronika Wielkopolski” 1990, nr 4, s. 59.

${ }^{16}$ Sprawozdanie stenograficzne z 10. posiedzenia Sejmu RP, 6 lutego 1931 r., lamy 107-109; z 16. posiedzenia Sejmu RP, 25 lutego 1931 r., łam 57; z 23. posiedzenia Sejmu RP, 16 i 17 marca 1931 r., łamy 122-123; ze 114. posiedzenia Sejmu RP, 9 lutego 1934 r., tam 28.

${ }^{17}$ „Poradnik Gospodarski” nr 47 z 22 XI 1936 r., s. 833-834.
} 
wana i sprawnie przeprowadzona reforma rolna miała - w jego przekonaniu przyczynić się do obniżenia bezrobocia na wsi. Młodzież, dla której zabrakło ziemi, powinna przechodzić do pracy w usługach, działających na rzecz mieszkańców wsi. O tym aspekcie reformy rolnej pisał Mikołajczyk w jednym z artykułów opublikowanych w 1938 roku: „Zatrudnienie nadmiaru bezrobotnych rąk na wsi musi następować przez reformę rolna, która powinna polegać na tworzeniu zdrowych, produktywnych gospodarstw chłopskich. Równocześnie zaś usuwanie bezrobocia na wsi musi następować przez przechodzenie młodego pokolenia rolniczego do handlu, rzemiosła, kupiectwa i spółdzielczości, gdyż wysiłki te muszą być wszechstronne i muszą budować całokształt polskiego życia gospodarczego" $"$.

Warunki, w jakich po II wojnie światowej przyszło działać Mikołajczykowi, nie sprzyjały wprowadzeniu przez Polskie Stronnictwo Ludowe (PSL) reform. Stronnictwo krytykowało realizowaną przez komunistów reformę rolną. W tej sprawie Mikołajczyk uważał, że „(...) dokonana przez państwo parcelacja obszarów dworskich jest formą uspołecznienia rolnictwa i początkiem dalszych reform rolnych". Według jego założeń reforma rolna to nie tylko wywłaszczenie, podział i nadanie nieruchomości rolnej, lecz także zabudowanie i zagospodarowanie osad, a więc kontynuacja reform rolnych zapowiedzianych w Manifeście Polskiego Komitetu Wyzwolenia Narodowego (PKWN) i dekrecie o reformie rolnej. W opinii Mikołajczyka, w wyniku reformy rolnej podzielono ziemię na zbyt małe parcele, co nie poprawiło istniejącej struktury gospodarstw. PSL opowiadało się za kontynuacją reformy, według której podstawą ustroju rolnego miało być jednorodzinne i samodzielne gospodarstwo chłopskie o obszarze od 5 do 20 ha, będące własnością i stanowiące podstawę życia rodziny na nim pracującej ${ }^{19}$.

Zdaniem Mikołajczyka, dla sił skupionych wokół PKWN reforma rolna była akcją mającą dwa zasadnicze cele: propagandowy - miała być symbolem demokratycznego charakteru nowej władzy, oraz polityczny - miała zapewnić obozowi PKWN masowe poparcie chłopów. Ten punkt widzenia prezentował na forum KRN, gdzie postulował przebudowę ustroju rolnego oraz dokończenie reformy rolnej. Opowiadał się za ustrojem rolnym opartym na indywidualnym gospodarstwie chłopskim i wzmocnionym ośrodkami kultury rolnej, stanowiącymi podstawę ustroju rolnego. $W$ jednym ze swoich wystąpień powiedział: „Uznajemy ustrój rolny oparty z jednej strony na indywidualnym gospodarstwie rolnym, a $\mathrm{z}$ drugiej strony wzmocniony ośrodkami kultury rolnej sta-

\footnotetext{
${ }^{18}$ "Poradnik Gospodarski” nr 7 z 13 II 1938 r., s. 105.

${ }^{19}$ L. Błądek, Wizja Polski w programach Polskiego Stronnictwa Ludowego 1945-1947, Warszawa 1996, s. 85-86.
} 
nowiącymi podstawę rozwoju doświadczalnictwa, nasiennictwa czy hodowli ${ }^{20}$. $\mathrm{Z}$ przeprowadzeniem reformy rolnej Mikołajczyk łączył również kwestię zagospodarowania tzw. ziem odzyskanych, gdyż miało to znaczenie nie tylko gospodarcze, ale również polityczne. Uważał, że przejęcie tego regionu przez polskich rolników przyczyni się do utrwalenia granic z Niemcami. Dał temu wyraz podczas Kongresu PSL w dniu 19 stycznia 1946 roku, gdy stwierdził: „(...) trzeba sobie jasno powiedzieć, że przecież musimy dokończyć dzieła reformy rolnej. Musimy pchnać o tyle akcje parcelacyjna, żeby te miliony hektarów, które na ziemiach zachodnich czekają na zaoranie rękoma chłopa polskiego, nie leżały odłogiem. Trwałość naszego państwa, zagospodarowanie i zaludnienie tych terenów zależy od najwcześniejszego objęcia tamtejszych terenów i zagospodarowania ich przez chłopów polskich. Równocześnie musi być prowadzona akcja komasacyjna, upełnorolnienia i przesiedlenia. Razem ujęte te działalności winny tworzyć pewną proporcję, pewną harmonię między nadwyżką rąk ludzkich na wsi, a między potrzebami przemysłu i miasta, które $\mathrm{w}$ ten sposób zagospodarowane, zmienią podstawowy charakter państwa; $\mathrm{z}$ państwa o przewadze rolniczej przekształcimy się $\mathrm{W}$ państwo rolniczo-przemysłowe",21.

\section{Zakończenie}

Stanisław Mikołajczyk w swojej pracy społecznej, niezależnie od jej etapu i zajmowanego stanowiska, dużo miejsca poświęcał sprawom wsi i rolnictwa. Tak głębokie zainteresowanie tą problematyką wynikało $\mathrm{z}$ jego osobistego doświadczenia gospodarskiego oraz z powszechnego - w tamtym okresie - przeświadczenia, iż droga do służby na rzecz państwa i narodu wiedzie przez lata pracy dla dobra wsi, gminy czy powiatu. Doświadczenia wyniesione z kierowania własnym gospodarstwem, wzbogacone pracą w organizacjach społeczno-gospodarczych, wspomagały jego działalność polityczna. $Z$ kolei nabywana we władzach stronnictwa i w Sejmie RP perspektywa widzenia spraw w ogólnym, politycznym kontekście nie pozwalała Mikołajczykowi zamykać się w fachowo-rolniczym partykularyzmie.

\footnotetext{
${ }^{20}$ L. Błądek, op. cit., s. 87; S. Mikołajczyk, W służbie narodu i państwa, Warszawa 1989, s. 32-33. ${ }^{21}$ Ibidem.
} 


\title{
Socioeconomic problems in Stanisław Mikołajczyk's activity
}

\begin{abstract}
Stanisław Mikołajczyk was peasant's activist, politician and statesman. In his activity he paid attention to activity of Farmer's Circles, peasant's cooperation as well as drawing up and realization of the agricultural reform. He considered that economic organizations run by farmers were basis of well functioning agriculture. It was a reason why he supported Society of Farmer's Circles in Poznań. He thought that farmer's interests were directly connected with peasant's cooperation. According to Mikołajczyk, they should by protection against the dishonest competition and should influence on profitability of production. $\mathrm{He}$ though that superfluous farmers should change their job and work in trade, craft and cooperation. Stanisław Mikołajczyk set about undertaking these problems in parliament and journalism, particularly in „Przewodnik Gospodarski”.
\end{abstract}


